\title{
Mycoplasma hominis expresses two variants of a cell-surface protein, one a lipoprotein, and one not
}

\author{
Søren A. Ladefoged and Gunna Christiansen \\ Author for correspondence: Søren A. Ladefoged. Tel: +4589421746. Fax: +4586196128. \\ e-mail: sorenl@biobase.dk
}

Department of Medical Microbiology and Immunology, Bartholin Building, University of Aarhus, DK-8000 Aarhus C, Denmark

\begin{abstract}
A protein similar to the previously characterized variable surface-exposed

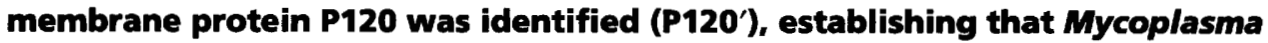
hominis PG21 possesses a novel gene family. The gene, p120', was sequenced and found to have some distinctive properties including a putative start codon of GTG, rather than the common ATG codon, and a coding region with a high $G+C$ content, characteristic of essential housekeeping genes in mycoplasmas. No sequence homology was found to known proteins. The genomic locations of the $p 120$ and $p 120^{\prime}$ genes were determined on the restriction map of five $\boldsymbol{M}$. hominis strains by PFGE. The genes were localized in two separate regions separated by more than 6 kb. Genes as well as proteins corresponding to P120' were identified in 24/24 $\mathrm{M}$. hominis isolates tested and no size variation was detected. P120' had a molecular mass of 98 kDa, 20 kDa smaller than P120 as estimated by SDS-PAGE. The protein was surface-exposed and associated with the mycoplasma membrane, but had predominantly hydrophilic characteristics upon Triton X-114 extraction. The N-terminal part of P120' had a hydrophobic leader sequence without the characteristics of a prolipoprotein. This might explain the membrane association of the protein. Unlike P120, which is frequently recognized by sera of patients seropositive for M. hominis, P120' was only rarely recognized. The conserved nature of the P120 gene family indicates that it has an essential, although currently unknown, function.
\end{abstract}

Keywords: reiterated genes, chromosome mapping, membrane proteins, $\mathrm{P} 120^{\prime}$ protein, P120 protein

\section{INTRODUCTION}

In spite of their uniquely small chromosome (Himmelreich et al., 1996; Fraser et al., 1995; Bak et al., 1969), and consequently limited biosynthetic capability, mycoplasmas have successfully adapted to a wide range of hosts. Mycoplasmas lack a cell wall, and the surface components of the single limiting cell membrane are thus essential for host adaptation. Mycoplasma hominis is an opportunistic pathogen causing gynaecological infections, and is increasingly detected in extragenital infections (Meyer \& Clough, 1993). Surface antigens of $M$. hominis vary considerably between isolates (Christiansen, 1992; Christiansen et al., 1994; Ladefoged et al., 1990, 1995, 1996; Jensen et al., 1995; Olson et al.,

The EMBL accession number for the sequence reported in this paper is Y13476. 1991b; Andersen et al., 1987). Even in isolates derived successively from a single chronically infected patient some antigenic variation was observed (Olson et al., 1991a). Three different surface-exposed membrane proteins have been characterized in detail in M. hominis. The Lmp family consists of two $135 \mathrm{kDa}$ surfaceexposed proteins, Lmp1 and Lmp3 (Ladefoged et al., 1995, 1996; Jensen et al., 1995). The corresponding genes, $\operatorname{lm} p 1$ and $\operatorname{lm} p 3$, are separated on the chromosome and contain multiple tandem repeated elements of $0.5 \mathrm{~kb}$. Two other genes, $\operatorname{lmp} 2$ and $\operatorname{lmp} 4$, also containing the repeated element, are located immediately downstream of $\operatorname{lmp} 1$ and $\operatorname{lmp} 3$, respectively, but are not translationally active in M. hominis PG21. M. hominis Lmp proteins are subject to mutational variation, due to the loss of repetitive elements resulting in size variation (Jensen et al., 1995). A role in agglutination of cells has been suggested for this protein. A putative adhesin of $M$. bominis, the variable adherence-associated (Vaa) anti- 
gen, identified as a lipoprotein, also shows variation in size and antigenicity between isolates (Henrich et al., 1996; Zhang \& Wise, 1996). The size variation is caused by loss or gain of central repetitive elements and the antigenic variation is associated with sequence variation in the C-terminal portion of Vaa. A gene in M. hominis (p120) encoding a $120 \mathrm{kDa}$ surface-exposed membrane protein (P120) with structural characteristics consistent with a lipoprotein has previously been characterized (Nyvold et al., 1997). The gene has been identified in all $M$. hominis strains examined, while the gene product is absent in a minority of the strains examined. The protein displays antigenic variation due to the presence of one hypervariable and two semivariable regions. No size variation has been observed. The hypervariable portion of P120 is often recognized by patients seropositive for $M$. hominis. An open reading frame on the $M$. hominis chromosome (ORF445), the $3^{\prime}$ end of which had been partly characterized previously (Ladefoged $\&$ Christiansen, 1994), was found to be similar to $p 120$. The aim of this study was to characterize the remainder of ORF445 (the $p 120^{\prime}$ gene), the $p 120$ gene family in 24 $M$. hominis isolates, and the product of the $p 120^{\prime}$ gene.

\section{METHODS}

Strains and growth conditions. M. hominis was cultivated in BEA medium (Andersen et al., 1987). The $24 \mathrm{M}$. bominis strains used in this study (PG21, P71, P7, P2, 4195, 93, 10, W2, 132 , 183, SC4, M1449, V2785, DC63, 5503, 4712, 7357, 1893, $3105,6188,5941,7488,7808,3449)$ have been described elsewhere (Christiansen \& Andersen, 1988). Escherichia coli strain XL-1 Blue (Stratagene) was used as host for the phagemid pBluescript (Stratagene) and pGEX (Pharmacia LKB Biotechonology). E. coli was cultivated in Luria-Bertani (LB) broth or Terrific Broth (TB) (Sambrook et al., 1989). E. coli $\mathrm{INV} \alpha \mathrm{F}^{\prime}$ was used as host for the $\mathrm{pCRII}$ vector (Invitrogen Corporation) and cultivated as described by the supplier. A pGEX vector containing the hypervariable domain of P120 from $M$. hominis PG21 and expressing the corresponding hypervariable peptide as a GST fusion protein was supplied by C. Nyvold (Nyvold et al., 1997).

Patient sera and monoclonal antibodies. Patient sera were obtained from the World Health Organization Reference Bank for Reproductive Immunology, Department of Medical Microbiology and Immunology, University of Aarhus, Denmark. The samples were originally collected for investigation of unexplained infertility (Mathur et al., 1985). The collection contained 195 sera, 21 of which were found positive in an indirect haemagglutination assay for $M$. hominis. Twenty-one sera from the same collection which were found negative were used as controls. Monoclonal antibodies mAb 30.1.5, directed against $M$. hominis elongation factor $\mathrm{Tu}$ (anti-EF-Tu) (Ladefoged \& Christiansen, 1991), mAb 43.2 directed against a surface-exposed integral membrane protein (Ladefoged $e t$ al., 1990 ), and $\mathrm{mAb} 522$, directed against the putative M. hominis adhesin Vaa (Zhang \& Wise, 1996; Ladefoged et al., 1990), and the polyclonal anti-P120 antibody pAb 121 (Nyvold et al., 1997) were used as controls in the immunoblotting experiments and/or the immunofluorescence assay.

DNA manipulation and Southern hybridization. $M$. hominis DNA was prepared as described previously (Ladefoged \& Christiansen, 1991). Plasmid DNA preparation by the alkaline lysis method, restriction endonuclease digestion and agarose gel electrophoresis were done according to Sambrook et al. (1989). DNA transfer to Hybond-N membrane (Amersham), DNA fragment labelling with $\left[\alpha-{ }^{32} \mathrm{P}\right] \mathrm{dATP}$ by nick-translation, and Southern hybridization were carried out using standard methods (Sambrook et al., 1989). For recovery of restriction fragments from agarose gels for cloning, electrophoresis was performed through a $1.0 \%$ low-melting-point agarose (SeaPlaque GTG Agarose, FMC Bio-Products). Bands were visualized by staining with ethidium bromide and examination by UV transillumination. Gel slices containing the appropriate restriction fragments were excised and melted at $62^{\circ} \mathrm{C}$ before purification by phenol/chloroform extraction and ethanol precipitation. PFGE was performed by the contour-clamped homogeneous-electric field (CHEF) technique using the CHEF-DR II system (Bio-Rad) as described previously (Ladefoged \& Christiansen, 1992). The genomic DNA was digested with SmaI, BamHI, XhoI and SalI (Boehringer Mannheim).

Nucleotide sequencing and sequence analysis. DNA sequencing of denatured double-stranded DNA was done by the methods of Hattori \& Sakaki (1986), using Sequenase version 2 (United States Biochemical). The sequence data were compiled and analysed with the Genetics Computer Group's Sequence Analysis Software Package Version 7.1-UNIX (Devereux et al., 1984).

Northern blotting. Total RNA was isolated by the single-step method of Chomczynski \& Sacchi (1987). Northern-blot hybridization of $M$. bominis RNA was performed using the procedure described by Sambrook et al. (1989), with a $0.24-9.5 \mathrm{~kb}$ RNA ladder (Life Technologies) as molecular mass markers.

Expression and purification of fusion proteins. To make a fusion protein containing part of the $\mathrm{P} 120^{\prime}$ protein, the primers 5'-GGATCCGAGGAATTTCAACTGGTGTCC-3' and $5^{\prime}$ CTCGAGCTGTTGTAATAGCATTAAG-3' were used to amplify a fragment of the gene by PCR. A BamHI and an XhoI site were introduced into the $5^{\prime}$ end of the upstream and downstream primers, respectively. PCR products were ligated to the vector $\mathrm{pCRII}$ and the ligated plasmid transformed into E. coli INV $\alpha \mathrm{F}^{\prime}$ according to the supplier's instructions (Invitrogen). The recombinant plasmid was digested with $X$ hoI and $B a m H I$ and the fragment containing part of the $p 120^{\prime}$ gene ligated to the expression vector pGEX-5X-3 (Pharmacia LKB Biotechonology). The ligated plasmid was transformed into $E$. coli XL-1 Blue. The $p 120^{\prime}$ fragment would thus be expressed fused to the $26 \mathrm{kDa}$ glutathione $S$-transferase (GST). Overnight cultures of E. coli XL-1 Blue containing the recombinant plasmid were diluted in fresh medium and grown for further $2 \mathrm{~h}$ at $37^{\circ} \mathrm{C}$. IPTG was added to $0.4 \mathrm{mM}$ and after a further $2 \mathrm{~h}$ of growth, the cells were pelleted and resuspended in PBS with $1 \%$ Triton X-100. Cells were lysed by sonication and, after centrifugation, the supernatant was mixed with glutathione-agarose beads (Sigma). The beads were transferred to spin-X tubes (Costar) and the fusion protein eluted by competition with free glutathione (Sigma).

Preparation of antiserum against GST-fusion protein. Antibodies against purified GST-fusion protein were raised in a New Zealand White rabbit. The rabbit was inoculated intramuscularly with $10 \mu \mathrm{g}$ antigen emulsified in Freund's incomplete adjuvant (Difco) on days $1,5,7,11,13$ and 18 . Intravenous inoculations of $10 \mu \mathrm{g}$ of antigen without adjuvant were given on days 39,49 , and 55 . On day 68 the rabbit was bled, and serum (anti-P120 ) was stored at $-20^{\circ} \mathrm{C}$.

SDSPAGE and immunoblotting. Separation of antigens under 
reducing conditions by SDS-PAGE and immunoblotting were performed as described by Andersen et al. (1987).

Triton X-114 extraction. Triton X-114 phase partitioning was performed essentially as described by Bordier (1981). $M$. hominis PG21 was grown to mid-exponential phase, harvested and washed in PBS. The cells were lysed on ice for $30 \mathrm{~min}$ in a buffer containing $1 \%$ Triton X-114, $10 \mathrm{mM}$ Tris/ $\mathrm{HCl}$ $\mathrm{pH} 7.4$ and $150 \mathrm{mM} \mathrm{NaCl}$ (protein concentration was adjusted to $1 \mathrm{mg} \mathrm{m}^{-1}$ ). The lysate was centrifuged at $20000 \mathrm{~g}$ for $30 \mathrm{~min}$ at $4{ }^{\circ} \mathrm{C}$ to pellet insoluble material. The supernatant was heated to $37^{\circ} \mathrm{C}$, at which temperature micelles are formed. Micelles were separated from the aqueous phase by sedimentation through a sucrose cushion, leaving the aqueous phase as a supernatant. The distribution of proteins in the Triton X-114 and the aqueous phases was analysed by SDSPAGE followed by immunoblotting.

Membrane and cytosol extraction. Separation of $M$. hominis cells into a membrane fraction and a cytosolic fraction was done according to Proft \& Herrmann (1994). Briefly, $M$. hominis PG21 was grown to mid-exponential phase, harvested, washed in PBS, and resuspended in $1 \mathrm{ml} \mathrm{H}_{2} \mathrm{O}$. The cells were disrupted by sonication eight times for $10 \mathrm{~s}$ on ice. Undisrupted cells were removed by centrifugation at $6000 \mathrm{~g}$ for $10 \mathrm{~min}$ at $4{ }^{\circ} \mathrm{C}$. The supernatant was centrifuged at $130000 \mathrm{~g}$ for $1 \mathrm{~h}$ at $4{ }^{\circ} \mathrm{C}$. The supernatant from this high-speed centrifugation was the cytosolic fraction. The pellet was resuspended in $1 \mathrm{ml} \mathrm{PBS}$ and recentrifuged at $130000 \mathrm{~g}$ for $1 \mathrm{~h}$ at $4{ }^{\circ} \mathrm{C}$. This pellet was the membrane fraction. The fractions were analysed by SDS-PAGE and immunoblotting.

Surface proteolysis of $\boldsymbol{M}$. hominis. To detect surface-exposed proteins, proteolysis was performed with trypsin on intact $M$. hominis cells. Cells were grown to mid-exponential phase, harvested, washed, and suspended in $1 \mathrm{ml}$ PBS. Two $250 \mu \mathrm{l}$ samples were each diluted to $750 \mu$ with PBS containing $500 \mu \mathrm{g}(4700 \mathrm{U})$ of trypsin V-S (Sigma). After 15 or $30 \mathrm{~min}$ incubation at $37^{\circ} \mathrm{C}$ the cells were pelleted at $15000 \mathrm{~g}$ for $5 \mathrm{~min}$ at $4^{\circ} \mathrm{C}$. The cells were lysed by adding $500 \mu \mathrm{l} 1 \times$ SDS sample buffer [ $1 \times$ SDS sample buffer is $0.0625 \mathrm{M}$ Tris/ $\mathrm{HCl} \mathrm{pH} \mathrm{6.8,}$ $2.3 \%(\mathrm{w} / \mathrm{v})$ SDS, $5 \%$ (v/v) 2-mercaptoethanol, $10 \%$ (v/v) glycerol, $0.05 \%$ bromophenol blue]. As controls two $250 \mu \mathrm{l}$ samples were disrupted by sonication three times for $10 \mathrm{~s}$. Five hundred micrograms of trypsin V-S was added to one sample and both samples were incubated for $30 \mathrm{~min}$ at $37^{\circ} \mathrm{C}$ followed by addition of $250 \mu 12 \times$ SDS sample buffer. The samples were analysed by SDS-PAGE and immunoblotting.

Immunofluorescence assay. To detect surface-exposed proteins an indirect immunofluorescence assay was performed (Ladefoged et al., 1990). M. hominis cells were immobilized on HeLa cells grown on coverslips. The medium used for cultivation was RPMI-1640 (GIBCO) containing $10 \mathrm{mM}$ HEPES buffer, $10 \%$ newborn calf serum, $1 \mathrm{mM}$ glutamine, and $100 \mathrm{IU}$ penicillin $\mathrm{ml}^{-1}$. Cells were incubated with primary antibodies for $30 \mathrm{~min}$ at room temperature with or without previous fixation in cold methanol. After a washing step, fluorescein-conjugated anti-rabbit or anti-mouse immunoglobulin (Dako), diluted 1:50 in growth medium containing $0.002 \%$ Evans Blue, was added and incubated for $30 \mathrm{~min}$ at room temperature. Cells not previously fixed were incubated with methanol. The coverslips were washed, air-dried and examined using a Leitz DMRBE fluorescence microscope (Leica Mikroskopie und Systeme) connected to a Sony 3CCD colour video camera and a SUN SPARC workstation. Washing procedures and dilution of antibodies were performed using growth medium. Prior to methanol fixation the coverslips were washed in PBS.

\section{RESULTS}

\section{Cloning and DNA sequence analysis of p120'}

The $3^{\prime}$ end of ORF445 was found in the gyrB region. To characterize this $p 120$ homologue the region $5^{\prime}$ to ORF445 was cloned and sequenced. By hybridization ORF445 was found on a $6 \cdot 3 \mathrm{~kb}$ DNA BamHI-XhoI fragment overlapping the previously sequenced $g y r B$ region. From mapping studies it was known that $M$. hominis PG21 contained only three small BamHI-XhoI fragments and only one of $6.3 \mathrm{~kb}$ (Ladefoged \& Christiansen, 1992). The BamHI-XboI fragments were cloned into pBluescript and a clone with an insert of $6.3 \mathrm{~kb}$ was selected. A ClaI-XhoI fragment containing the $5^{\prime}$ end of ORF445 was subcloned from this plasmid. The subclone was sequenced bidirectionally by using subclones made from the available restriction sites, and by using synthetic oligonucleotide primers complementary to the characterized sequence. One large ORF of 2745 nucleotides was identified and designated $p 120^{\prime}$. The first codon in $p 120^{\prime}$ was predicted to be GTG. The structural gene was preceded by a putative Shine-Dalgarno sequence (AGGA) located nine nucleotides upstream of the initiation codon. The region upstream of $p 120^{\prime}$ contained, based on homology with the E. coli consensus promoter, a putative transcriptional element $(-10$, TATAAT; -35 , TTGATT). Between the putative promoter and the predicted translational start a palindromic sequence of $14 \mathrm{bp}$ was identified with the potential to form a stem-loop structure. The $\mathrm{G}+\mathrm{C}$ content of $p 120^{\prime}$ was $33.1 \mathrm{~mol} \%$. The $\mathrm{G}+\mathrm{C}$ content across the gene varied between 24 and $44 \mathrm{~mol} \%$ (using a window of $100 \mathrm{bp}$ ). The regions of highest $\mathrm{G}+\mathrm{C}$ content were near the $5^{\prime}$ end and in the $3^{\prime}$ half of the gene. The predicted amino acid sequence was 915 amino acids, corresponding to a molecular mass of $104 \mathrm{kDa}$ and a predicted isoelectric point of $\mathrm{pH} 5.9$. The deduced protein sequence included 12 tryptophan residues, each encoded by TGA (Yamao et al., 1985) and only one cysteine residue. Numerous potential trypsin cleavage sites were identified through the entire peptide, making trypsin a rational choice for proteolysis studies (see below). A typical $\mathrm{N}$-terminal signal peptide was identified consisting of a stretch of primary hydrophobic residues preceded by three basic amino acids. Using the methods of von Heijne (1986) a signal peptidase I cleavage site was identified. Hydropathy analysis with the Kyte-Doolittle algorithm indicated that the protein is mainly hydrophilic and the signal peptide was the only domain which displayed significant hydrophobicity (data not shown). PSORT (available on the World Wide Web at http://psort.nibb.ac.jp) did not detect any potential transmembrane domains by the methods of Klein et al. (1985) other than the N-terminal signal sequence.

\section{The P120 gene family}

The deduced amino acid sequences of P120 and P120' were compared (Fig. 1). The overall similarity was $48 \%$. The carboxyl-terminal 587 residues of $\mathrm{P} 120^{\prime}$ showed 


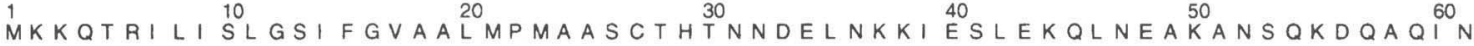
DLMKQL QE T ${ }^{70} K N N S K T$ I EEKEKLVKKL QEDLNKI QQERTAKY QAELNAANKAI VEIPKKYEE

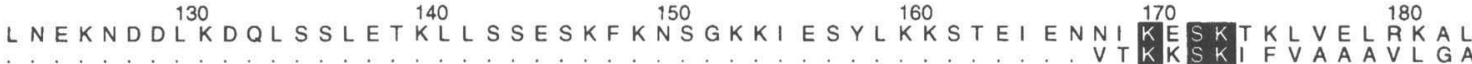

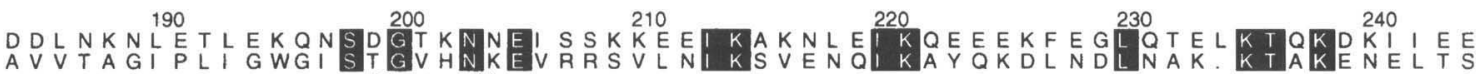

$210 \quad 220$

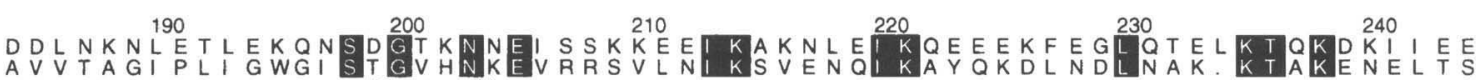
recombinant peptide

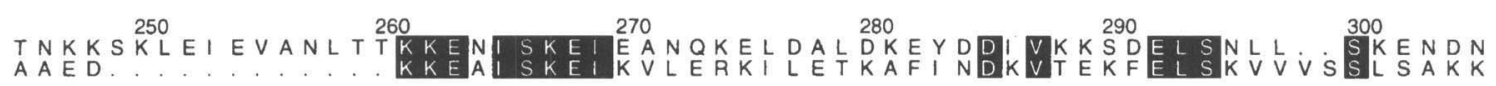

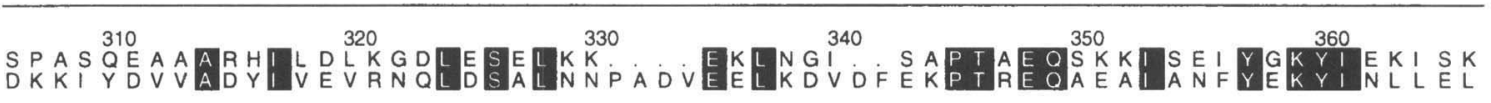

DKK

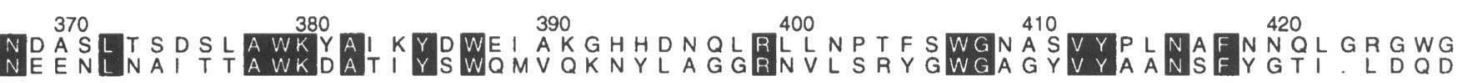

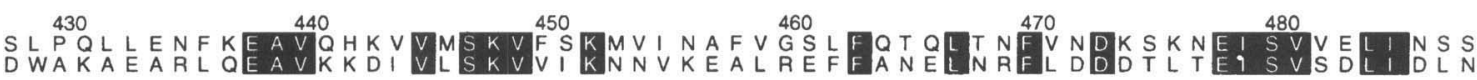

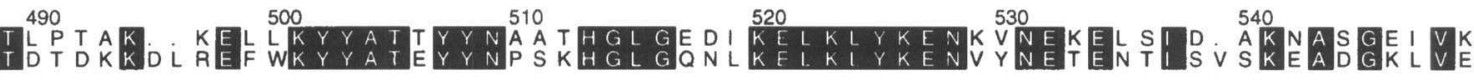

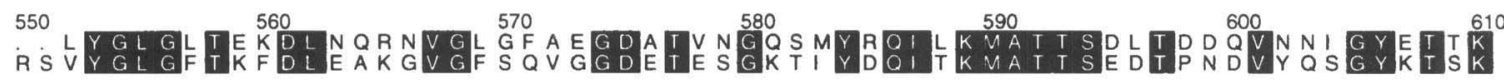

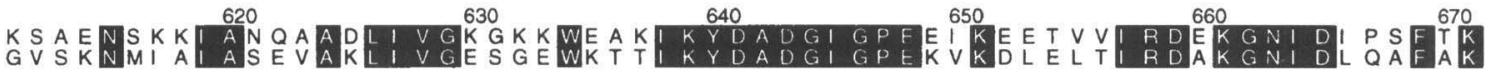

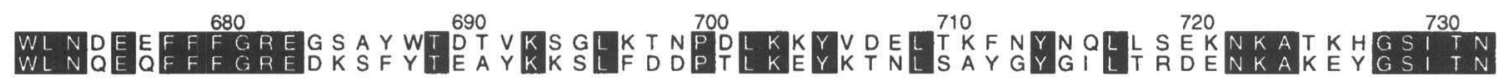

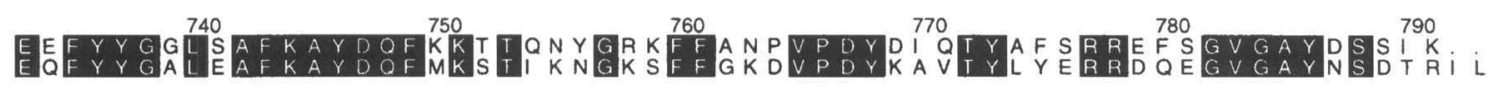

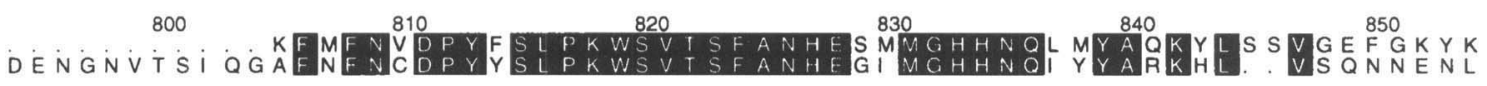

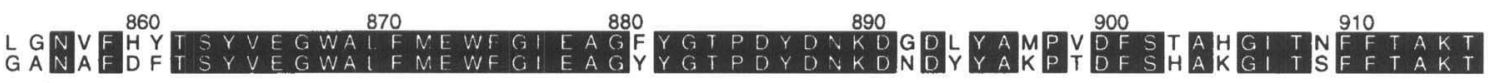

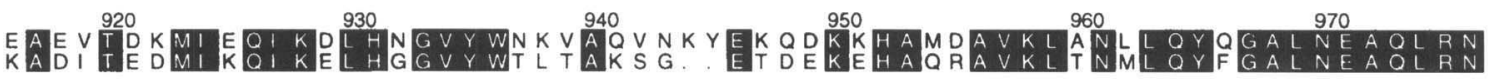

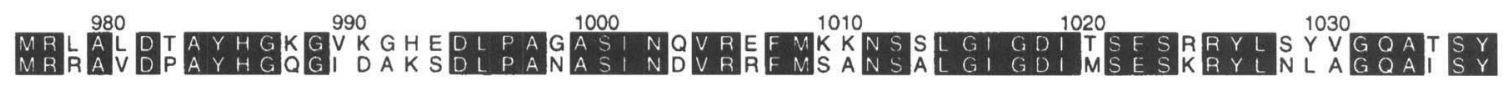

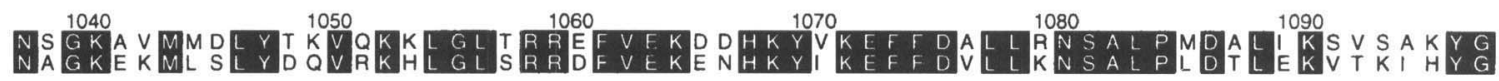
$\stackrel{1}{1100}$ V E K K K

Fig. 1. Alignment of deduced amino acid sequences of $P 120^{\prime}$ and $P 120$ (Nyvold et al., 1997) from M. hominis PG21. The recombinant peptide expressed as a fusion protein in the pGEX vector (pG120-1) and used for immunization is underlined. Identical amino acids are shaded.

strong similarity to $\mathrm{P} 120$, with $58 \%$ identical amino acids and regions of up to 19 consecutive amino acids showing $100 \%$ identity. The first 328 amino acids of P120' displayed less similarity ( $28 \%$ identity). The larger molecular mass of P120 compared to P120' was due to an 167 amino acid extension of P120 at the N-terminal end with no counterpart in $\mathrm{P} 120^{\prime}$. A comparison of the $5^{\prime}$ untranslated regions of the $p 120$ and $p 120^{\prime}$ genes did 


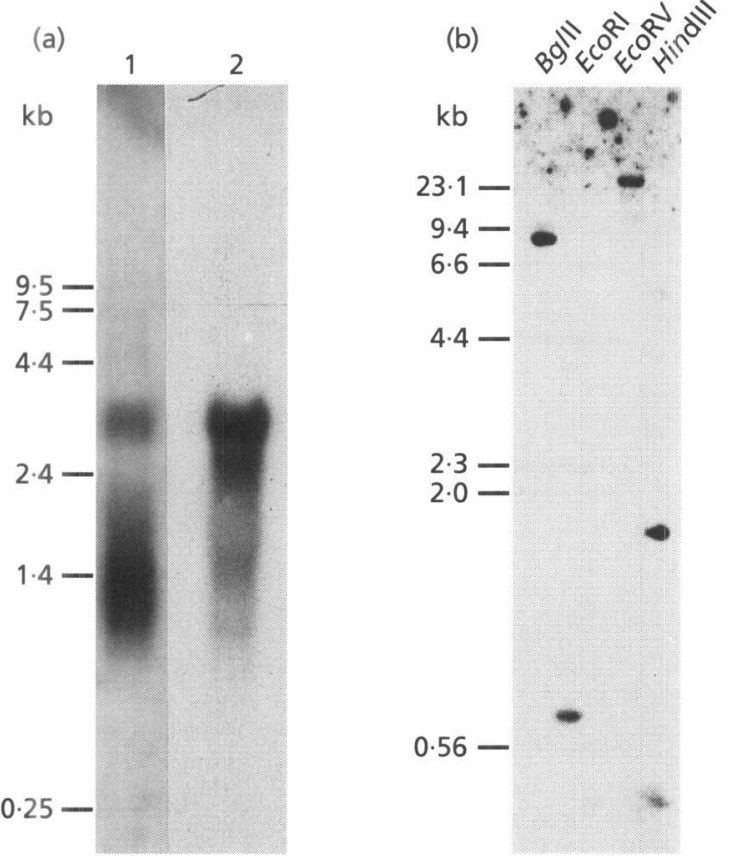

Fig. 2. (a) Northern blot of total RNA from $M$. hominis PG21. A probe derived from the $5^{\prime}$ end of $p 120^{\prime}$ (pG120-1; lane 1) and a probe derived from the $3^{\prime}$ end of $p 120^{\prime}$ (pE12H-23; lane 2) were used for hybridization. The positions of the standard markers are shown on the left. (b) Southern blotting of PG21 DNA cleaved with the restriction endonucleases indicated and probed with pG120-1. The positions of the standard markers are shown on the left.

not reveal any conservation in the primary structure. Apart from the homology to P120, database searching with the P120' sequence did not identify any significant similarities to known DNA or amino acid sequences.

\section{Transcription of the $120^{\prime}$ gene in M. hominis}

A transcript of $3.2 \mathrm{~kb}$ had been identified previously (Ladefoged \& Christiansen, 1994) using a hybridization probe $(\mathrm{pE} 12 \mathrm{H}-23)$ derived from the $3^{\prime}$ region of $p 120^{\prime}$, which is similar to that of $p 120$ (Fig. 2a, lane 2). To confirm that the hybridizing RNA fragment was a $p 120^{\prime}$, and not a p120 transcript (the length of which has also been determined to be $3.2 \mathrm{~kb}$; Nyvold et al., 1997), Northern blot analysis was carried out using the $p 120^{\prime}$ specific hybridization probe pG120-1. The probe detected an mRNA of about $3.2 \mathrm{~kb}$, a size in accordance with earlier results and correlating with the length of the coding region, implying a monocistronic organization (Fig. 2a, lane 1). The Northen blotting indicated some degradation of the mRNA transcript during preparation. A control experiment demonstrating the specificity of the $p 120^{\prime}$ probe pG120-1 is shown in Fig. 2(b). pG120-1 hybridized exclusively to a BglII fragment of $8.6 \mathrm{~kb}$, an EcoRI fragment of $0.77 \mathrm{~kb}$, an $E c o \mathrm{RV}$ fragment of $20 \mathrm{~kb}$, and two HindIII fragments of $1.8 \mathrm{~kb}$ and $0.2 \mathrm{~kb}$, as expected from the restriction mapping data obtained from the cloning and subsequent sequen- (a)

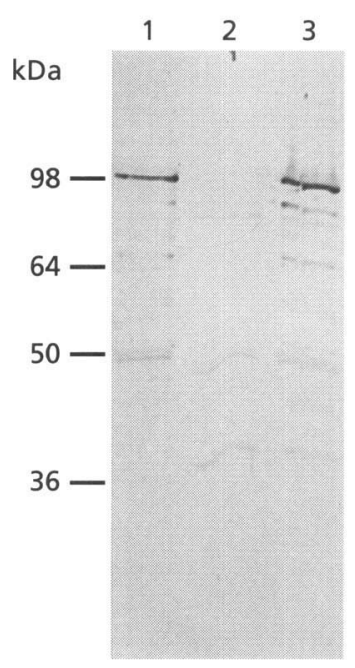

(b)

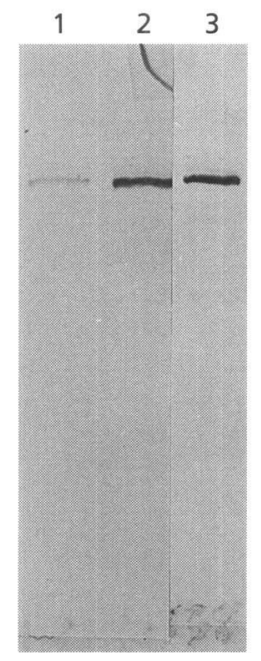

Fig. 3. Immunoblotting of $M$. hominis preparations with antiP120'. Proteins were separated on SDS-10\% polyacrylamide gels, transferred to nitrocellulose membranes and probed with anti-P120'. (a) A cytosolic and a membrane fraction were isolated by ultracentrifugation. Lanes: 1 , membrane fraction; 2 , cytosolic fraction; 3, cell lysate. (b) $M$. hominis cells were subjected to Triton X-114 phase fractionation. Aqueous (lane 2) and Triton X-114 (lane 1) phases were separated by SDS-PAGE. Total M. hominis cell lysate (lane 3 ) was analysed together with the protein preparations.

cing of the region (the $0.2 \mathrm{~kb}$ HindIII fragment was too small to be detected on the gel shown in Fig. 2b).

\section{Detection of $\mathrm{P} 120$ ' by monospecific polyclonal antibodies}

Part of the $p 120^{\prime}$ gene was cloned into the expression vector $\mathrm{pGEX}$, and the fusion protein expressed was purified and used to raise antibodies. The location of the expressed region, indicated in Fig. 1, extended from the first to the second TGA codon in $p 120^{\prime}$. Expression of part of $\mathrm{P} 120^{\prime}$ as a glutathione S-transferase fusion protein (GST-P120') was achieved, and analysis by SDSPAGE revealed the expression of a $44 \mathrm{kDa}$ protein in accordance with the predicted size. The fusion protein was purified and examination by SDS-PAGE demonstrated limited degradation during purification, leaving the majority of the product intact. To identify P120' in $M$. hominis, rabbit antibodies were raised to the GSTP120' fusion protein. The antiserum (anti-P120') specifically recognized a protein of $98 \mathrm{kDa}$ in $M$. hominis PG21 (Fig. 3a, lane 3). The molecular mass determined by SDS-PAGE ( $98 \mathrm{kDa}$ ) was in good agreement with the mass deduced from the amino acid sequence $(104 \mathrm{kDa})$.

\section{Detection of $\mathrm{P}^{120}$ in different $M$. hominis strains and Mycoplasma species}

Immunoblots of whole-cell proteins of $24 \mathrm{M}$. hominis strains were probed with the rabbit anti-P120' serum. The serum detected a $98 \mathrm{kDa}$ band in all $M$. hominis 
(a)

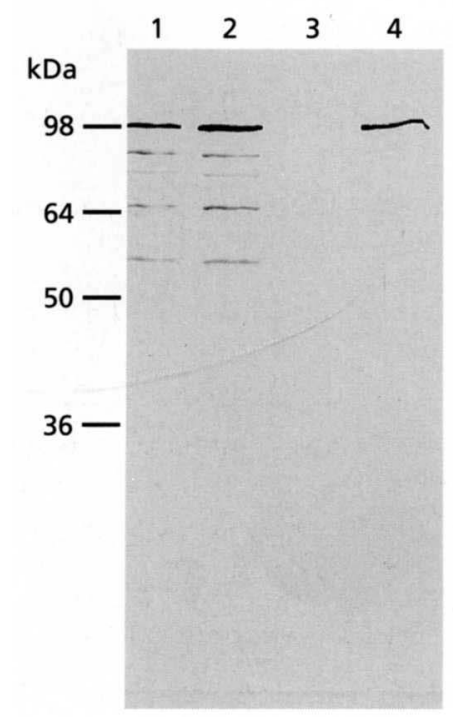

(b)

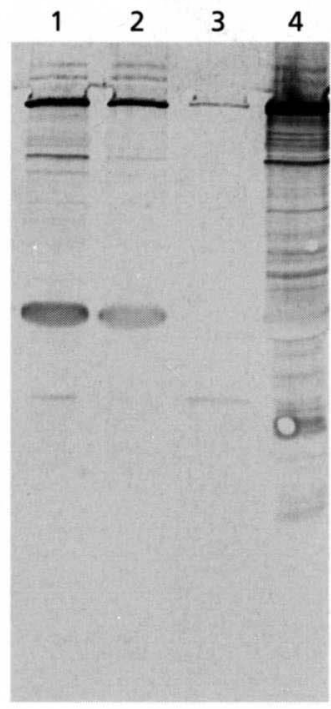

(c)

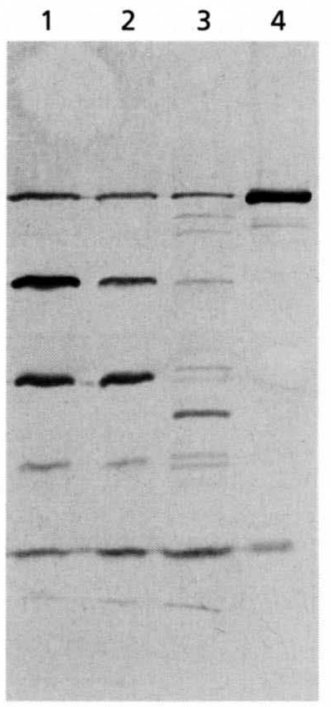

(d)

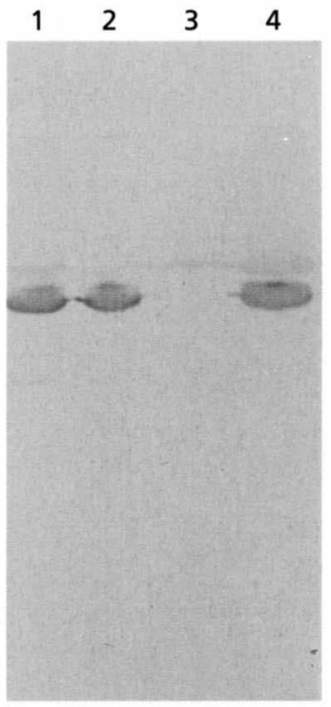

Fig. 4. Surface proteolysis of $M$. hominis with trypsin. Intact $M$. hominis cells were treated with trypsin for 15 or 30 min. $M$. hominis cells disrupted by sonication before trypsin treatment and cells disrupted by sonication but without trypsin treatment served as controls. Proteins were separated on SDS-10\% polyacrylamide gels, transferred to nitrocellulose membranes and probed with (a) the polyclonal anti-P120' antibody, (b) the polyclonal anti-P120 antibody, (c) the mAb 43.2, and (d) the mAb anti-EF-Tu. Lanes (same designation in each panel): 1, whole cells, trypsin 30 min; 2, whole cells, trypsin 15 min; 3, sonicated cells, trypsin $30 \mathrm{~min}$; 4, sonicated cells, no trypsin.

strains tested. No specific reactions were observed between anti-P120' and other Mycoplasma species pathogenic for humans (M. buccale, M. pneumoniae, $M$. orale, $M$. fermentans, $M$. salivarium or $M$. genitalium)

\section{Topology of the P120' molecule}

M. hominis lysate was separated into a cytosolic and a membrane fraction by differential ultracentrifugation. Each fraction was subjected to SDS-PAGE followed by immunoblotting with anti-P120'. P120' was found solely in the membrane fraction (Fig. 3a, lane 1). The monoclonal antibodies $\mathrm{mAb} 30.1 .5$, directed against the cytoplasmic protein elongation factor $\mathrm{Tu}$, and $\mathrm{mAb}$ $43 \cdot 2$, directed against a surface-exposed integral membrane protein, were used in control experiments and recognized proteins of the expected size primarily in the cytosolic and membrane fractions, respectively.

Following Triton X-114 partitioning, proteins from the aqueous phase and the Triton X-114 phase were separated by SDS-PAGE and immunoblotted with anti$\mathrm{P} 120^{\prime}$. $\mathrm{P} 120^{\prime}$ was primarily partitioned into the hydrophilic phase (Fig. $3 \mathrm{~b}$, lane 2). In control experiments $\mathrm{mAb} 30.1 .5$ and $\mathrm{mAb} 43.2$ reacted with proteins of the expected size exclusively in the aqueous phase and the Triton X-114 phase, respectively.

The potential surface exposure of $\mathrm{P} 120^{\prime}$ was analysed by surface proteolysis of intact mycoplasmas using trypsin. Immunoblot analysis of trypsin-treated intact cells with anti-P120' antiserum showed partial degradation of
$\mathrm{P} 120^{\prime}$, indicating surface exposure of the protein (Fig. 4a). Trypsin treatment of sonicated cells resulted in the complete degradation of $\mathrm{P} 120^{\prime}$ (Fig. 4a). When mAb 43.2 and anti-P120 were used in parallel experiments as positive controls degradation was seen in analysis of trypsin-treated intact cells, as expected from the surface exposure of the corresponding antigens (Fig. 4b, c). In each of the experiments (Fig. $4 a-c$ ) the antigens in intact cells degraded to varying extents, leaving varying amounts of antigen intact. The sonicated and subsequently trypsin-treated antigens were far more thoroughly degraded. This indicates a varying degree of trypsin accessibility to the proteins in the intact cell membrane. The cytosolic elongation factor $\mathrm{Tu}$ was not degraded by trypsin treatment of intact $M$. hominis cells but was completely degraded when cells were disrupted by sonication, as expected from its intracellular location (Fig. 4d).

Direct evidence for the association of $\mathrm{P} 120^{\prime}$ with the cell membrane and exposure of anti-P120 epitopes on the surface was obtained by immunofluorescence microscopy (Fig. 5). The bacteria showed positive immunofluorescence with anti-P120 on fixed (Fig. 5a) as well as unfixed cells (Fig. 5b), indicating surface exposure of the $\mathrm{N}$-terminal part of $\mathrm{P} 120^{\prime}$ recognized by anti-P120'. When $\mathrm{mAb} 522$ and anti-p120 were assessed as positive controls, immunofluorescence was observed on both fixed and unfixed cells. The reactivity of anti-P120 and $\mathrm{mAb} 522$ was of equal intensity while the reactivity of anti-P120 was slightly stronger. Anti-EF-Tu showed immunofluorescence on methanol-fixed (and consequently permeabilized) cells (Fig. 5c) but not on 

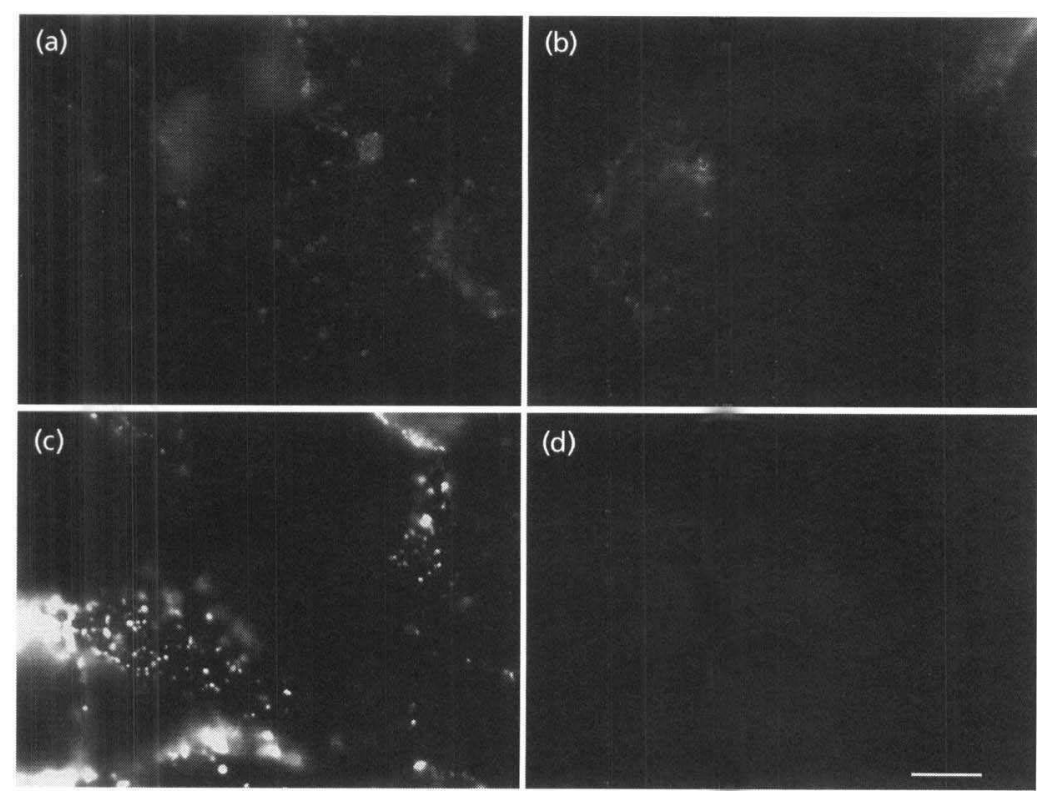

Fig. 5. Immunofluorescence analysis of $M$. hominis PG21. Monolayers of HeLa cells were infected with $M$. hominis and reacted with anti-P120' with (a) or without (b) prior fixation with methanol. Control experiments with (c) or without (d) fixation were performed with a monoclonal antibody reacting with the cytosolic protein EF-Tu. Bar, $10 \mu \mathrm{m}$.

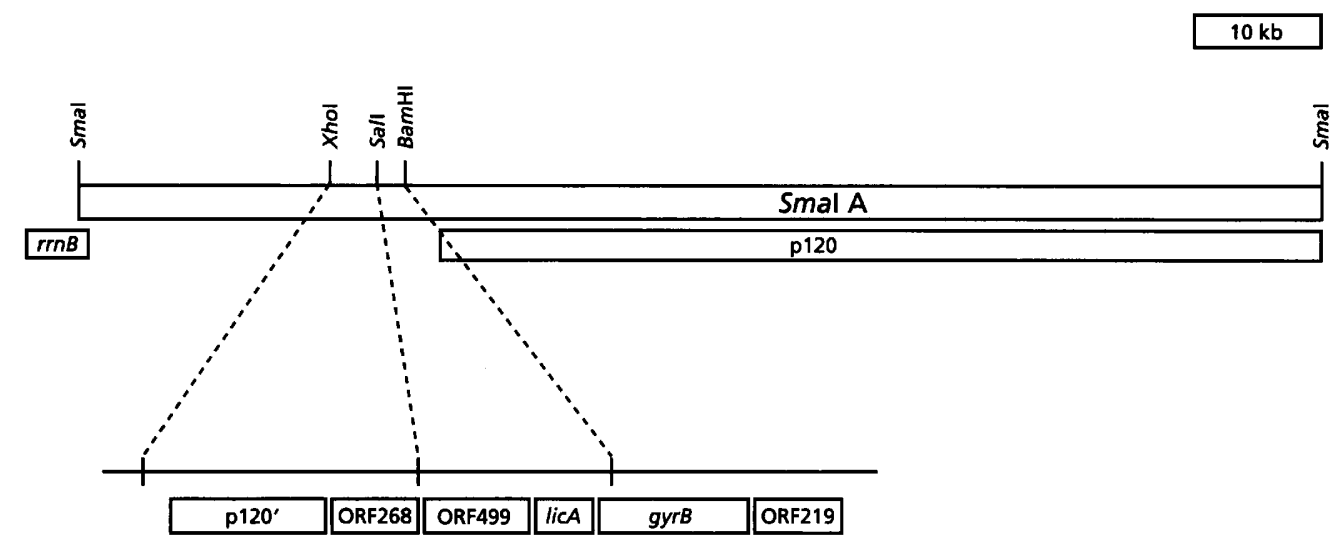

Fig. 6. Location of $p 120$ and $p 120$ on the $100 \mathrm{~kb}$ Smal A fragment of the $M$. hominis PG21 chromosome. Restriction nuclease sites for Smal, BamHI, Xhol, and Sall are shown. The locations of the ribosomal RNA operon (rrnB) and the gyrB, licA, and $p 120^{\prime}$ genes are indicated together with three ORFs (ORF268, ORF499, and ORF219) without functional assignment. The position of $p 120$ is indicated as precisely as possible given the resolution of the restriction map.

unfixed (intact) cells (Fig. 5d), as expected for a cytosolic protein. Preimmune serum gave a faint reaction on fixed as well as unfixed cells. From these data we conclude that $\mathrm{P} 120^{\prime}$ is a membrane protein associated with the exterior surface of the membrane.

\section{Humoral immune response in humans to P120'}

To determine whether $\mathrm{P} 120^{\prime}$ was an antigen recognized in vivo, the recombinant $\mathrm{P} 120^{\prime}$ peptide was tested against human serum samples by immunoblotting. Of 21 serum samples positive by an indirect haemagglutination assay for antibodies against $M$. hominis, one (sample designated 169) gave a strong positive reaction, while the remaining 20 sera gave no reaction (data not shown). All 21 serum samples negative for antibodies against $M$. hominis by indirect haemagglutination gave no reaction.
The serum sample positive in immunoblotting when tested against the recombinant $\mathrm{P} 120^{\prime}$ peptide was negative when tested against the hypervariable domain of P120 from $M$. hominis PG21 expressed as a GSTfusion protein in the pGEX vector, excluding any crossreaction with the GST portion of the fusion protein.

\section{Localization of the $p 120^{\prime}$ gene in $M$. hominis strains}

A probe cloned from the $5^{\prime}$ end of $p 120^{\prime}$ hybridized to the genomic DNA of all 24 strains of $M$. hominis under high-stringency conditions, indicating the presence of a highly conserved region in these strains. Some degree of restriction fragment length polymorphism was observed in the $p 120^{\prime}$ gene as well as in the flanking regions. Several genes have been mapped on the genome of five M. hominis strains (M. hominis PG21, 132, 4195, 93 and 
7488) by PFGE (Ladefoged \& Christiansen, 1992). The $p 120^{\prime}$ and a $p 120$-specific probe were hybridized to chromosomal DNA digested with SmaI, BamHI, XhoI and SalI and the genes were localized on the maps of these strains. The $p 120^{\prime}, p 120$ and $g y r B$ genes were found to have the same relative positions in all strains. Part of the chromosomal map of M. hominis PG21 is shown in Fig. 6. In all strains $p 120^{\prime}$ and $p 120$ were placed on homologous SmaI fragments (fragment SmaI A, ranging in size from 100 to $106 \mathrm{~kb}$, having homologous positions on the map of the five strains). In each strain $p 120^{\prime}$ was positioned on a $4 \mathrm{~kb}$ XhoI-SalI fragment within the $S m a I$ A fragment close to the $g y r B$ gene. In each strain $p 120$ and gyrB lay on the same BamHI fragment (fragment BamHI A). Given the resolution of the restriction maps the distance between $p 120$ and $p 120^{\prime}$ was estimated to be at most $80 \mathrm{~kb}$ in M. hominis PG21, $44 \mathrm{~kb}$ in M. hominis 4195, $84 \mathrm{~kb}$ in M. hominis $132,86 \mathrm{~kb}$ in M. hominis 93 , and $46 \mathrm{~kb}$ in M. hominis 7488.

\section{DISCUSSION}

In order to understand the pathogenesis of mycoplasmas we need to understand the interactions between the proteins on the cell surface and the host. In this study we have identified and characterized a $98 \mathrm{kDa}$ surface protein, $\mathrm{P} 120^{\prime}$, of $M$. hominis, and the corresponding gene, $p 120^{\prime}$.

\section{Features of the $p 120^{\prime}$ gene}

In the completely sequenced genome of Mycoplasma genitalium $7 \%$ of the identified ORFs have a proposed GTG start codon, with the remaining ORFs starting with ATG (Dalphin et al., 1997). A GTG start rather than an ATG start in $p 120^{\prime}$ has been established with considerable certainty. The GTG start predicts a protein with a molecular mass $(104 \mathrm{kDa})$ in accordance with the mass determined by SDS-PAGE $(98 \mathrm{kDa})$ while an ATG start predicts a much smaller protein $(79 \mathrm{kDa})$. Additionally, the polyclonal anti-P120' antibody identifying $\mathrm{P}^{120^{\prime}}$ in $M$. hominis has been established by raising antibodies to a peptide derived from the region between the proposed GTG start and the first ATG codon in the ORF.

In many bacteria with a low genomic $\mathrm{G}+\mathrm{C}$ content, including mycoplasmas, it is known that the functional importance of genes is correlated with the $\mathrm{G}+\mathrm{C}$ content of the coding regions, the housekeeping genes having the highest $\mathrm{G}+\mathrm{C}$ content (Muto \& Osawa, 1987). $M$. hominis has a low genomic G + C content $(28-29 \mathrm{~mol} \%$; Neimark, 1971) and the housekeeping genes sequenced so far (tuf, Ladefoged \& Christiansen, 1991; fts Y, Ladefoged \& Christiansen, 1997; gyrB, Ladefoged \& Christiansen, 1994; lysS, Ozkokmen et al., 1994; arcC, Harasawa et al., 1992; licA, Ladefoged \& Christiansen, 1994; opp B, EMBL X99740; deoC, EMBL Z27121; upp, EMBL Z27121) all have a G + C content higher than the average for the genome. The high $\mathrm{G}+\mathrm{C}$ content of $p 120^{\prime}(33.1 \mathrm{~mol} \%)$ might thus reflect a conserved amino acid sequence necessary to maintain a prominent function in the cell, or recent acquisition from an exogenous source.

\section{Gene duplication in M. hominis}

The $p 120$ and $p 120^{\prime}$ genes were located in two separate regions on the chromosome of $M$. hominis PG21. The genes were found in equivalent positions in $M$. hominis PG21, 4195, 132, 93 and 7488, confirming the conserved gene order observed earlier in $M$. hominis strains (Ladefoged \& Christiansen, 1992). The $p 120$ and $p 120^{\prime}$ genes have probably evolved by gene duplication followed by diversification and are thus serving similar but not identical functions. From Southern hybridization data it is known that the $g y r B$ gene downstream of $p 120^{\prime}$ and the region immediately upstream of $p 120^{\prime}$ are not duplicated, suggesting that only the $p 120$ genes and not a larger block of the genome has been duplicated.

Further characterization of the regions is needed to prove this hypothesis. Several examples of duplicated genes exist among mycoplasmas but the most extreme is found in Mycoplasma gallisepticum, where the pMGA gene encoding a cell-surface haemagglutinin is estimated to be present in 70 copies, accounting for up to $16 \%$ of the genome size in one strain (Baseggio et al., 1996). The pMGA family is believed to be part of a surface antigen variation system. In contrast to the $p 120$ family only one pMGA gene is assumed to be expressed in each cell (Glew et al., 1995).

\section{Cellular location of P120}

In our efforts to localize the $\mathrm{P} 120^{\prime}$ protein in M. hominis we performed experiments which are generally accepted to elucidate membrane association and surface exposure of bacterial proteins. P120 is considered to be a lipidmodified membrane protein due to the presence of lipoprotein consensus sequence elements and its hydrophobic characteristics on Triton X-114 extraction (Nyvold et al., 1997; Christiansen et al., 1994). The results of the Triton X-114 extraction, membrane extraction, surface proteolysis, and immunofluorescence assays using $\mathrm{P} 120^{\prime}$-specific antisera suggest that $\mathrm{P} 120^{\prime}$ is a surface-exposed membrane-associated protein, which in contrast to P120 is without lipid modifications. The mechanism by which $\mathrm{P} 120^{\prime}$ associates with the membrane surface is as yet unclear. The sequence data combined with the biochemical properties suggest a model for $\mathrm{P}^{\prime 2} 0^{\prime}$ either as a class II integral membrane protein anchored to the plasma membrane by an uncleaved $\mathrm{N}$-terminal signal peptide (von Heijne \& Gavel, 1988), or as a peripheral membrane protein bound non-covalently to the membrane either between the peripheral protein and the lipid polar headgroups or to charged amino acids on other membrane protein constituents (McElhaney, 1992; Singer \& Nicolson, 1972). According to the amino acid sequence, $P 120^{\prime}$ contains a signal peptidase I cleavage site, but since neither this enzyme nor the corresponding gene has been identified in the completely sequenced mycoplasma 
chromosomes (Fraser et al., 1995; Himmelreich et al., 1996) the actual fate of the signal peptide is uncertain. P120' only contains a single cysteine residue, making it unlikely that disulphide bonds are of importance in anchoring of the protein to the membrane.

\section{Immune responses against $\mathbf{P 1 2 0}$ and $\mathbf{P 1 2 0}$}

Human serum samples positive for antibodies against $M$. hominis have previously all been found to react with several proteins, including proteins with a molecular mass equivalent to $\mathrm{P} 120^{\prime}$, in immunoblotting using $M$. hominis lysate as antigen (Nyvold et al., 1997). Using the recombinant GST-P120' as antigen, P120', although only detected in one case, was found to be recognized by the human immune system, giving rise to a strong reaction upon immunoblotting. Only a minor part of the $\mathrm{P}^{120^{\prime}}$ antigen was expressed in the recombinant protein and it thus remains to be established whether the mature $\mathrm{P} 120^{\prime}$ protein is recognized by a larger proportion of seropositive samples.

\section{Significance of multigene families in the mycoplasmas}

The number of lipoproteins in mycoplasmas is substantially higher than in bacteria with cell walls, implying that mycoplasmas in many instances require lipid modification in order to secure these otherwise hydrophilic proteins to the membrane (Wieslander et al., 1992). In the completely sequenced genome of $M$. pneumoniae, 36 of a total of 46 proposed lipoproteins are found in six gene families containing from 4 to 16 members (Himmelreich et al., 1996, 1997). The lipoprotein families also include 20 proteins with sequence similarities to lipoproteins but without the functional lipoprotein signal peptide. At present only four translational products from these lipoprotein gene families have been identified in M. pneumoniae ( $\mathrm{R}$. Herrmann, 1997:bttp://zmbh.uni-heidelberg.de/M_pneumoniae). In $M$. hominis two lipoproteins have been identified, P120 and Vaa. In contrast to P120, Vaa is encoded by a single-copy gene. Only a few functions have been attributed to lipoproteins in mycoplasmas. Besides a few enzymic functions proposed from sequence homology (Himmelreich et al., 1996; Fraser et al., 1995; Dudler et al., 1988; Gilson et al., 1988), lipoproteins are supposed to protect organisms from the humoral response by adaptive mutational systems creating extensive antigenic diversity at the cell surface (Citti et al., 1997; Bhugra et al., 1995; Lysnyansky et al., 1996; Markham et al., 1994). $\mathrm{P} 120$ and $\mathrm{P} 120^{\prime}$ display no size variation and are expressed, with few exceptions, in all $M$. bominis strains tested, indicating a function incompatible with extensive alterations.

Because of the small $M$. hominis genome it is reasonable to suppose that each gene confers a selective advantage for the cell. Further studies are required to determine the functional role of P120 and P120' and the significance of the highly similar regions in the primary structure of these proteins.

\section{ACKNOWLEDGEMENTS}

This research was supported by the Danish Health Research Council (grants 12-0850-1 and 12-1620-1), Aarhus University Research Foundation, Novo's Foundation, and Fonden til Lægevidenskabens Fremme. We thank K. S. Sørensen and I. Andersen for excellent technical assistance.

\section{REFERENCES}

Andersen, H., Birkelund, S., Christiansen, G. \& Freundt, E. A. (1987). Electrophoretic analysis of proteins from Mycoplasma bominis strains detected by SDS-PAGE, two-dimensional gel electrophoresis and immunoblotting. J Gen Microbiol 133, 181-191.

Bak, A. L., Black, F. T., Christiansen, C. \& Freundt, E. A. (1969). Genome size of mycoplasmal DNA. Nature 224, 1209-1210.

Baseggio, N., Glew, M. D., Markham, P. F., Whithear, K. G. \& Browning, G. F. (1996). Size and genomic location of the pMGA multigene family of Mycoplasma gallisepticum. Microbiology 142, 1429-1435.

Bhugra, B., Voelker, L. L., Zou, N., Yu, H. \& Dybvig, K. (1995). Mechanism of antigenic variation in Mycoplasma pulmonis: interwoven, site-specific DNA inversions. Mol Microbiol 18, 703-714.

Bordier, C. (1981). Phase separation of integral membrane proteins in Triton X-114 solution. J Biol Chem 256, 1604-1607.

Chomczynski, P. \& Sacchi, N. (1987). Single-step method of RNA isolation by acid guanidinium thiocyanate-phenol-chloroform extraction. Anal Biochem 162, 156-159.

Christiansen, G. (1992). Genetic variation in natural populations. In Mycoplasmas: Molecular Biology and Pathogenesis, pp. 561-573. Edited by J. Maniloff, R. N. McElhaney, L. R. Finch \& J. B. Baseman. Washington, DC: American Society for Microbiology.

Christiansen, G. \& Andersen, H. (1988). Heterogeneity among Mycoplasma hominis strains as detected by probes containing parts of ribosomal ribonucleic acid genes. Int J Syst Bacteriol 38, 108-115.

Christiansen, G., Mathiesen, S. L., Nyvold, C. \& Birkelund, S. (1994). Analysis of a Mycoplasma hominis membrane protein, P120. FEMS Microbiol Lett 121, 121-127.

Citti, C., Kim, M. F. \& Wise, K. S. (1997). Elongated versions of Vlp surface lipoproteins protect Mycoplasma byorbinis escape variants from growth-inhibiting host antibodies. Infect Immun 65, 1773-1785.

Dalphin, M. E., Brown, C. M., Stockwell, P. A. \& Tate, W. P. (1997). The translational signal database, TransTerm: more organisms, complete genomes. Nucleic Acids Res 25, 246-247.

Devereux, J., Haeberli, P. \& Smithies, O. (1984). A comprehensive set of sequence analysis programs for the VAX. Nucleic Acids Res 12, 387-395.

Dudler, R., Schmidhauser, C., Parish, R. W., Wettenhall, R. E. \& Schmidt, T. (1988). A mycoplasma high-affinity transport system and the in vitro invasiveness of mouse sarcoma cells. EMBO J 7, 3963-3970.

Fraser, C. M., Gocayne, J. D., White, O. \& 26 other authors (1995). The minimal gene complement of Mycoplasma genitalium. Science 270, 397-403.

Gilson, E., Alloing, G., Schmidt, T., Claverys, J. P., Dudler, R. \& Hofnung, M. (1988). Evidence for high affinity binding-protein dependent transport systems in gram-positive bacteria and in Mycoplasma. EMBO J 7, 3971-3974. 
Glew, M. D., Markham, P. F., Browning, G. F. \& Walker, I. D. (1995). Expression studies on four members of the pMGA multigene family in Mycoplasma gallisepticum S6. Microbiology 141, 3005-3014.

Harasawa, R., Koshimizu, K., Kitagawa, M., Asada, K. \& Kato, I. (1992). Nucleotide sequence of the arginine deiminase gene of Mycoplasma hominis. Microbiol Immunol 36, 661-665.

Hattori, M. \& Sakaki, Y. (1986). Dideoxy sequencing method using denatured plasmid templates. Anal Biochem 152, 232-238.

von Heijne, G. (1986). A new method for predicting signal sequence cleavage sites. Nucleic Acids Res 14, 4683-4690.

von Heijne, G. \& Gavel, Y. (1988). Topogenic signals in integral membrane proteins. Eur J Biochem 174, 671-678.

Henrich, B., Kitzerow, A., Feldmann, R. C., Schaal, H. \& Hadding, U. (1996). Repetitive elements of the Mycoplasma hominis adhesin p50 can be differentiated by monoclonal antibodies. Infect Immun 64, 4027-4034.

Himmelreich, R., Hilbert, H., Plagens, H., Pirkl, E., Li, B. C. \& Herrmann, R. (1996). Complete sequence analysis of the genome of the bacterium Mycoplasma pneumoniae. Nucleic Acids Res 24, $4420-4449$.

Himmelreich, R., Plagens, H., Hilbert, H., Reiner, B. \& Herrmann, R. (1997). Comparative analysis of the genomes of the bacteria Mycoplasma pneumoniae and Mycoplasma genitalium. Nucleic Acids Res 25, 701-712.

Jensen, L. T., Ladefoged, S., Birkelund, S. \& Christiansen, G. (1995). Selection of Mycoplasma hominis PG21 deletion mutants by cultivation in the presence of monoclonal antibody 552 . Infect Immun 63, 3336-3347.

Klein, P., Kanehisa, M. \& DeLisi, C. (1985). The detection and classification of membrane-spanning proteins. Biochim Biophys Acta 815, 468-476.

Ladefoged, S. A. \& Christiansen, G. (1991). Analysis of the nucleotide sequence of the Mycoplasma hominis tuf gene and its flanking region. FEMS Microbiol Lett 79, 133-140.

Ladefoged, S. A. \& Christiansen, G. (1992). Physical and genetic mapping of the genomes of five Mycoplasma hominis strains by pulsed-field gel electrophoresis. J Bacteriol 174, 2199-2207.

Ladefoged, S. A. \& Christiansen, G. (1994). Sequencing analysis reveals a unique gene organization in the $\operatorname{gyr} B$ region of Mycoplasma hominis. J Bacteriol 176, 5835-5842.

Ladefoged, S. A. \& Christiansen, G. (1997). A GTP binding protein of Mycoplasma hominis: a small sized homolog to the signal recognition receptor Ftsy. Gene 201, 37-44.

Ladefoged, S. A., Hauge, S., Andersen, H., Birkelund, S. \& Christiansen, G. (1990). Use of monoclonal antibodies for detection of antigen variation in Mycoplasma bominis. Int J Med Microbiol (Suppl) 20, 634-639.

Ladefoged, S. A., Birkelund, S., Hauge, S., Brock, B., Jensen, L. T. \& Christiansen, G. (1995). A 135-kilodalton surface antigen of Mycoplasma hominis PG21 contains multiple directed repeated sequences. Infect Immun 63, 212-223.

Ladefoged, S. A., Jensen, L. T., Brock, B., Birkelund, S. \& Christiansen, G. (1996). Analysis of 0.5-kilobase-pair repeats in the Mycoplasma hominis lmp gene system and identification of gene products. J Bacteriol 178, 2775-2784.

Lysnyansky, I., Rosengarten, R. \& Yogev, D. (1996). Phenotypic switching of variable surface lipoproteins in Mycoplasma bovis involves high-frequency chromosomal rearrangements. $J \mathrm{Bac}$ teriol 178, 5395-5401.

McElhaney, R. N. (1992). Membrane structure. In Mycoplasmas: Molecular Biology and Pathogenesis, pp. 113-155. Edited by J. Maniloff, R. N. McElhaney, L. R. Finch \& J. B. Baseman. Washington, DC: American Society for Microbiology.

Markham, P. F., Glew, M. D., Sykes, J. E., Bowden, T. R., Pollocks, T. D., Browning, G. F., Whithear, K. G. \& Walker, I. D. (1994). The organisation of the multigene family which encodes the major cell surface protein, pMGA, of Mycoplasma gallisepticum. FEBS Lett 352, 347-352.

Mathur, S., Genco, P. V., Møller, B. \& Mardh, P. A. (1985). Antibodies to microbial, leukocyte and organ antigens. J Reprod Immunol 8, 353-358.

Meyer, R. D. \& Clough, W. (1993). Extragenital Mycoplasma hominis infections in adults: emphasis on immunosuppression. Clin Infect Dis 17, Suppl 1, S243-S249.

Muto, A. \& Osawa, S. (1987). The guanine and cytosine content of genomic DNA and bacterial evolution. Proc Natl Acad Sci USA 84, 166-169.

Neimark, H. C. (1971). Division of mycoplasmas into subgroups. $J$ Gen Microbiol 63, 249-263.

Nyvold, C., Birkelund, S. \& Christiansen, G. (1997). The Mycoplasma hominis P120 membrane protein contains a 216 amino acid hypervariable domain that is recognized by the human immune response. Microbiology 143, 675-688.

Olson, L. D., Renshaw, C. A., Shane, S. W. \& Barile, M. F. (1991a). Successive synovial Mycoplasma hominis isolates exhibit apparent antigenic variation. Infect Immun 59, 3327-3329.

Olson, L. D., Shane, S. W., Karpas, A. A., Cunningham, T. M., Probst, P. S. \& Barile, M. F. (1991b). Monoclonal antibodies to surface antigens of a pathogenic Mycoplasma hominis strain. Infect Immun 59, 1683-1689.

Ozkokmen, D., Birkelund, S. \& Christiansen, G. (1994). Characterization of a Mycoplasma hominis gene encoding lysyl-tRNA synthetase (LysRS). FEMS Microbiol Lett 116, 277-282.

Proft, T. \& Herrmann, R. (1994). Identification and characterization of hitherto unknown Mycoplasma pneumoniae proteins. Mol Microbiol 13, 337-348.

Sambrook, J., Fritsch, E. F. \& Maniatis, T. (editors). (1989). Molecular Cloning : a Laboratory Manual. Cold Spring Harbor, NY: Cold Spring Harbor Laboratory.

Singer, S. J. \& Nicolson, G. L. (1972). The fluid mosaic model of the structure of cell membranes. Science 175, 720-731.

Wieslander, A., Boyer, M. J. \& Wroblewski, H. (1992). Membrane protein structure. In Mycoplasmas: Molecular Biology and Pathogenesis, pp. 93-112. Edited by J. Maniloff, R. N. McElhaney, L. R. Finch \& J. B. Baseman. Washington, DC: American Society for Microbiology.

Yamao, F., Muto, A., Kawauchi, Y., Iwami, M., Iwagami, S., Azumi, Y. \& Osawa, S. (1985). UGA is read as tryptophan in Mycoplasma capricolum. Proc Natl Acad Sci USA 82, 2306-2309.

Zhang, Q. \& Wise, K. S. (1996). Molecular basis of size and antigenic variation of a Mycoplasma bominis adhesin encoded by divergent vaa genes. Infect Immun 64, 2737-2744.

Received 1 July 1997; revised 14 October 1997; accepted 12 November 1997. 